\title{
Ethylene and fruit ripening: From illumination gas to the control of gene expression, more than a century of discoveries
}

\author{
Ana Lúcia Soares Chaves ${ }^{1}$ and Paulo Celso de Mello-Farias ${ }^{2}$ \\ ${ }^{1}$ Departamento de Bioquímica, Instituto de Química e Geociências, Universidade Federal de Pelotas, \\ Pelotas, RS, Brazil. \\ ${ }^{2}$ Engenharia de Bioprocessos e Biotecnologia, Universidade Estadual do Rio Grande do Sul, Novo \\ Hamburgo, RS, Brazil.
}

\begin{abstract}
The effects of ethylene on plants have been recognized since the Nineteenth Century and it is widely known as the phytohormone responsible for fruit ripening and for its involvement in a number of plant growth and development processes. Elucidating the mechanisms involved in the ripening of climacteric fruit and the role that ethylene plays in this process have been central to fruit production and the improvement of fruit quality. The biochemistry, genetics and physiology of ripening has been extensively studied in economically important fruit crops and a considerable amount of information is available which ranges from the ethylene biosynthesis pathway to the mechanisms of perception, signaling and control of gene expression. However, there is still much to be discovered about these processes and the objective of this review is to present a brief historic account of how ethylene became the focus of fruit ripening research as well as the development and the state-of- art of these studies at both biochemical and genetic levels.
\end{abstract}

Key words: climacteric fruits, plant hormones, ethylene biosynthesis, ripening, signal transduction.

Received: December 15, 2004; Accepted: December 14, 2005.

\section{History of Ethylene Research}

Nineteenth Century coal gas (illumination gas), produced from the partial combustion of coal, was an important source of light. In 1858, Fahnestock attributed the deterioration of a collection of plants cultivated in a Philadelphia greenhouse and showing signs of senescence and leaf abscission to the presence of illumination gas, but although he detected the presence of hydrocarbons he was unable to identify the component responsible for such effects. Some years later, in 1864, Girardin verified that trees growing close to places where illumination gas was leaking showed the same symptoms of senescence, and also demonstrated that ethylene was present in this gas. In fact, illumination gas contained 5\% ethylene and its physiological effects on plants had been observed for many years without being formally attributed to illumination gas (Zegzouti, 1997).

In 1886 Neljubov discovered that ethylene was the biologically active component of illumination gas when he noticed that illumination gas was responsible for the hori-

Send correspondence to Ana Lúcia Soares Chaves. Departamento de Bioquímica, Instituto de Química e Geociências, Universidade Federal de Pelotas, Campus Universitário $\mathrm{s} / \mathrm{n}^{\circ}$, Caixa Postal 354 , 96010-900 Pelotas, RS, Brazil. E-mail: alschaves@yahoo.com.br. zontal growth of etiolated pea seedlings which he had been cultivating. Several observations were subsequently made on the effects of illumination gas on plants and the typical symptoms of ethylene action described, including the inhibition of stem and root growth, leaf abscission, horizontal growth and plant senescence. In 1924, Denny demonstrated that smoke from kerosene combustion in lanterns used to de-green citrus fruits contained ethylene as the active ingredient and demonstrated that ethylene is a fruit-ripening agent that acts in very small amounts. All these observations were in agreement with numerous historic reports, such as those from China where incense was burnt in closed chambers to activate the ripening of pears (Zegzouti, 1997).

In the 1930s most of the physiological effects of ethylene on plants had already been described (Pech et al., 1992) and after this period ethylene became the object of numerous studies due to commercial interest related to its action on the ripening and conservation of fruit. After a long time using ethylene in growth and development manipulations, it was presupposed that this gas was an endogenous growth regulator. The chemical proof that plant tissues naturally produce ethylene was provided in 1934 by Gane in an experiment involving the collection of gas emitted by ripening apples. Later it was demonstrated that a strong increase in ethylene production was associated with 
peak in respiration during tomato ripening (Zegzouti, 1997).

All these reports on biological activity of ethylene led scientists to consider this endogenous growth regulator as a plant hormone (Abeles et al., 1992) produced by plants in amounts that can reach $500 \mathrm{~nL} \mathrm{~g}^{-1} \mathrm{~h}^{-1}$ but is active at very low concentrations from 10 to $100 \mathrm{~nL} \mathrm{~L}^{-1}$. A number of studies have demonstrated the intervention of this hormone in several phases of plant growth and development, such as fruit ripening (Abeles et al., 1992), seed germination, leaf and flower senescence and abscission, root growth and development, leaf and flower senescence and somatic embryogenesis. It is also known that ethylene is synthesized in response to different type of stress, such as wounding, very low and very high temperatures, flooding or drought, treatments with other hormones, heavy metals and attack by pathogens (Pech et al., 1992).

The ethylene biosynthesis pathway has now been completely elucidated due to advances in the techniques of biochemical analyses (Yang and Hoffman, 1984; Kende, 1993) (Figure 1). The first step of this metabolic pathway involves the conversion of S-adenosyl-L-methionine (SAM) to 1-aminocyclepropane-1-carboxylic acid (ACC), catalyzed by the enzyme ACC synthase (ACCS). The second step, catalyzed by ACC oxidase (ACCO), consists in the conversion of ACC to ethylene, $\mathrm{CO}_{2}$ and $\mathrm{HCN}$. Alternatively, ACC can be malonylated, producing N-malonyl ACC by the action of N-malonyl transferase (NMT), reducing substrate availability for ACCO. In some specific cases, ethylene regulates its own production (auto-catalytic biosynthesis) inducing de novo synthesis of ACCS and ACCO (Yang and Hoffman, 1984). The genes encoding these two enzymes have been cloned and characterized in several plant species and are known to belong to multigenic families whose members show strongly regulated expression (Kende, 1993) and are differentially expressed in response to external stimuli including flooding, infection by pathogens and wounding as well as internal stimuli such as fruit ripening and senescence (Johnson and Ecker, 1998).

\section{Ethylene Action and Gene Expression Regulation}

Plants show a great diversity of physiological responses to ethylene according to the stage of development and tissue being analyzed (Table 1). Ethylene promotes ripening of tomato and other climacteric fruits (i.e. fruits whose ripening is affected by ethylene), while wild-type Arabidopsis thaliana plants treated with ethylene show a dramatic inhibition of cellular expansion. Seedlings of this species exposed to ethylene show the triple response, i.e. curvature of the apical hook, radial hypocotyl thickening and root shortening. Tomato plants with an intact ethylene signal transduction cascade are more predisposed to damage and necrosis caused by pathogen attack than plants with

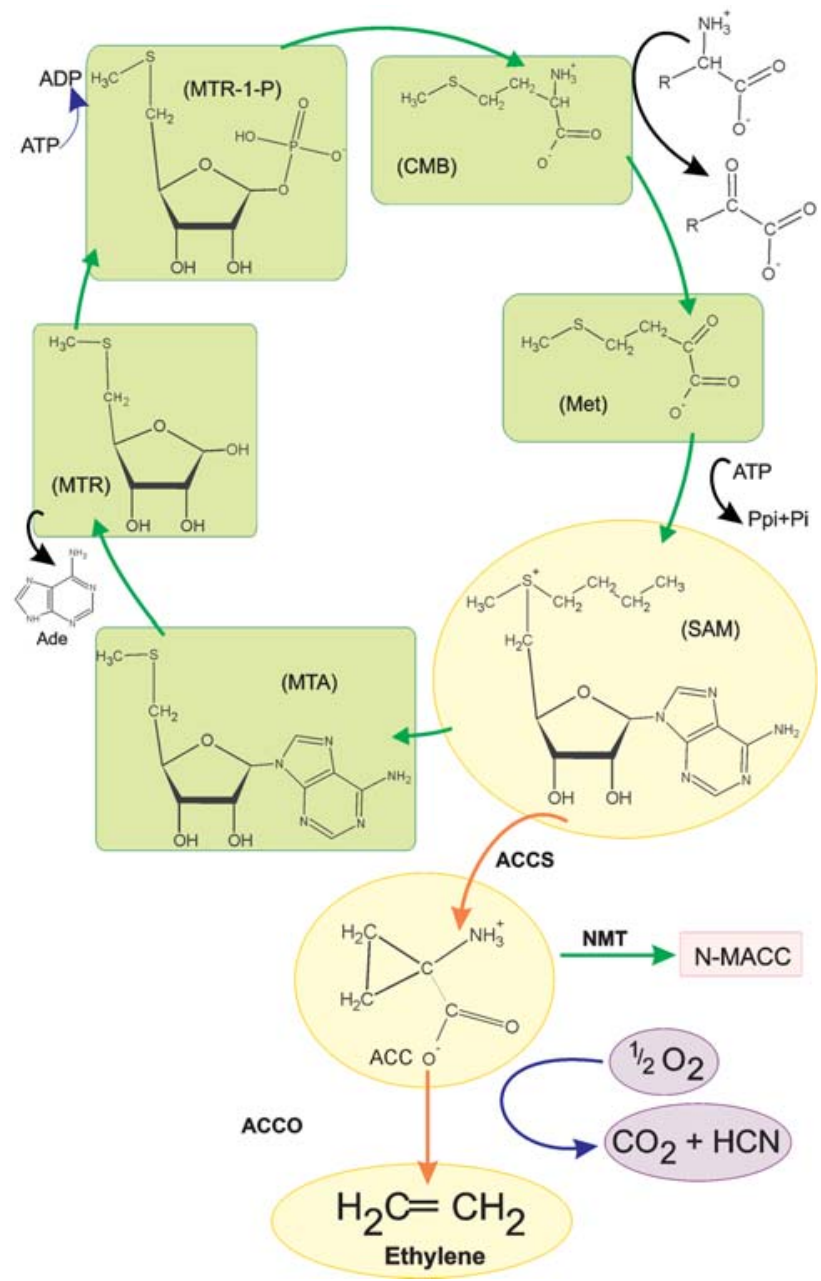

Figure 1 - Ethylene biosynthesis pathway (yellow) and its relationship to the methionine cycle (green). ACC: 1-aminocyclopropane-1-carboxylic acid; ACCS: ACC synthase; ACCO: ACC oxidase; Ade: adenosine; ADP: adenosine 5'-diphosphate; ATP: adenosine 5'-triphosphate; CMB: 2-keto-4-metilbutyrate; MTA: 5'-metilthioadenosine; MTR: 5-metilthioribose; MTR-1-P: 5-metilthioribose-1-phosphate; N-MACC: N-malonyl ACC; NMT: N-malonyl transferase; SAM: S-adenosyl methionine (adapted from Yang and Hoffman, 1984).

non-intact systems. Treatment with ethylene causes roothair formation in almost all epidermal cells located at the junction of two cells of the internal adjacent layer and also accelerates the senescence of mature flowers by promoting petal shriveling and abscission (Johnson and Ecker, 1998). The diversity and amplitude of these responses presuppose the existence of several molecular mechanisms of regulation by ethylene and with the advent of molecular biology techniques in the past fifteen years many genes whose expression is regulated by ethylene have been isolated and characterized.

\section{Ethylene and fruit ripening}

Fruits can be classified into two major groups based on the intervention of ethylene during maturation. Nonclimacteric fruits are those whose maturation does not 
Table 1 - Effects of ethylene on plant development. (+) stimulus; (-) inhibition (from Ayub, 1995).

\begin{tabular}{ll}
\hline Organ or tissue & Action \\
\hline Seeds, spores and pollen & Germination $(+)$ \\
Seeds, shoots, tubercles, bulbs & Loss of dormancy $(+)$ \\
Somatic embryos & Embryogenesis $(+)$ \\
Coleoptiles, roots & Growth (-); sometimes (+) \\
& Modifications on geotropism \\
Petioles & Epinasty (+) \\
Roots & aerenchyma formation (+) \\
& Adventitious roots (+) \\
Flowers & Absorbent hair $(+)$ \\
& Floral induction in Bromeliaceous $(+)$ \\
& Flower differentiation (?) in Cucurbi- \\
& taceous $(+)$ \\
Fruits & Senescence $(+) ;$ Abscission $(+)$ \\
& Growth $(+)$ \\
Estomates & Ripening $(+)$ \\
Laticiferous & Degreening of citrus $(+)$ \\
\hline
\end{tabular}

depend on ethylene, such as cherry, strawberry and pineapple. Climacteric fruits, such as tomato, avocado, melon, apple, pear, peach and kiwifruit are characterized by an extraordinary increment in ethylene production which accompanies the respiratory peak during ripening, called the 'climacteric crisis' (Abeles et al., 1992). During maturation several structural and biochemical changes occur in fruit which confer on them specific organoleptic qualities, such as modifications in the external aspect, texture and flavor of the fruit (Seymour et al., 1993). For example, the change in the color of tomato fruits results from transformation of chloroplasts into chromoplasts and from the degradation of chlorophyll, as well from the accumulation of pigments such as carotenes and lycopenes, which are responsible for the orange and red color of the fruit (Gray et al., 1992). The tomato maturation process is also accompanied by alterations in the texture of the fruit, more specifically the loss of firmness, due to structural changes in the principal cell wall components (cellulose, hemicellulose and pectin). Finally, the accumulation of sugars such as glucose and fructose and organic acids in vacuoles and the production of complex volatile compounds is responsible for the aroma and flavor of the fruit (Seymour et al., 1993).

Most physical and biochemical changes that characterize the tomato ripening process are associated with alterations in the activity of enzymes such as invertase (Iki et al., 1978) and polygalacturonase (Tucker and Grierson, 1982), which increase during the ripening of tomato fruits, or citrate synthase and malate dehydrogenase (Jefferey et al., 1984) which decreases considerably during ripening. Examples of changes in enzymatic activity of several plant species exposed to ethylene are summarized in Table 2 .
Table 2 - Examples of change in enzymatic activity in some plant species, after ethylene treatment (Abeles et al.., 1992).

\begin{tabular}{|c|c|}
\hline Enzyme & Species \\
\hline \multicolumn{2}{|l|}{ Activity increased } \\
\hline$\alpha$-amylase & Rice (Oriza sativa, L.) \\
\hline Arginine decarboxylase & Tobacco (Nicotiana tabaccum, L.) \\
\hline$\beta$-1,3-Glucanase & Pea (Pisum sativum, L.) (seedlings) \\
\hline$\beta$-Cyanoalanine synthase & Pimento (Capsicum annuum, L.) (fruit) \\
\hline$\beta$-Galactosidase & Carrot (Daucus carota, L.) (roots) \\
\hline Chalcone synthase & Beans (Phaseolus vulgaris, L.) (leaves) \\
\hline Chlorophyllase & Lemon (Citrus sp.) (fruit) \\
\hline Cellulase & Sunflower (Helyanthus annuиs, L.) \\
\hline DNA polimerase & Potato (Solanum tuberosum, L.) \\
\hline ACC oxidase & Avocado (Persea americana, Mill.) (fruit) \\
\hline Invertase & $\begin{array}{l}\text { Tomato (Lycopersicon esculentum, Mill.) } \\
\text { (fruit) }\end{array}$ \\
\hline Lysine decarboxylase & $\begin{array}{l}\text { Tomato (Lycopersicon esculentum, Mill.) } \\
\text { (fruit) }\end{array}$ \\
\hline Malonyl transferase & $\begin{array}{l}\text { Tomato (Lycopersicon esculentum, Mill.) } \\
\text { (fruit) }\end{array}$ \\
\hline Peroxidase & Cucumber (Cucumis sativus, L.) \\
\hline Poliphenol oxidase & Potato (Solanum tuberosum, L.) \\
\hline Proteinase & $\begin{array}{l}\text { Tomato (Lycopersicon esculentum, Mill.) } \\
\text { (plant) }\end{array}$ \\
\hline Superoxide dismutase & Beans (Phaseolus vulgaris, L.) (leaves) \\
\hline RNA polimerase & Potato (Solanum tuberosum, L.) \\
\hline \multicolumn{2}{|l|}{ Activity decreased } \\
\hline Acid invertase & Melon (Cucumis melo, L.) \\
\hline ACC synthase & Squash (fruit) \\
\hline$\beta$-amylase & Potato (Solanum tuberosum, L.) \\
\hline Arginine decarboxylase & Pea (Vicia sativa, L.) (seedlings) \\
\hline SAM decarboxylase & Pea (Vicia sativa, L.) (seedlings) \\
\hline Cytrate synthase & $\begin{array}{l}\text { Tomato (Lycopersicon esculentum, Mill.) } \\
\text { (fruit) }\end{array}$ \\
\hline
\end{tabular}

Several studies have already demonstrated that ethylene controls most of the events associated with the fruit ripening process (Pech et al., 1992).

\section{Gene expression regulation by ethylene during ripening}

The diversity and amplitude of fruit physiological and biochemical responses to ethylene suggested that this phytohormone controls the expression of a large number of genes. The phenomenon of climacteric crisis is accompanied by important changes in gene expression and several cDNAs have been isolated corresponding to mRNAs that accumulate abundantly during the development and fruit ripening processes or in response to ethylene (Pech et $a l .$, 1992). Other observations related to the action of ethylene on the physiology of fruit ripening reinforced this hypothesis. When submitted to either specific ethylene 
biosynthesis inhibitors or inhibitors which block the action of ethylene, tomato fruits showed strong inhibition of ripening but when fruits in the green-ripe stage were exposed to exogenous ethylene maturation could be activated (Gray et al., 1992).

Using classical methods of differential screening of ripe fruit cDNA banks, several genes whose expression is regulated by ethylene or induced during ripening were isolated and cDNA clones corresponding to genes strongly expressed during tomato ripening were isolated (Mansson et $a l ., 1985)$. To study ethylene-associated events during ripening, cDNAs corresponding to the mRNAs of ethyleneregulated genes have been isolated and characterized (Mansson et al. 1985) and it has been demonstrated that the expression of some of these clones is regulated by ethylene (Pech et al., 1992). Subsequently, other important genes expressed during ripening were isolated, identified and characterized, such as those encoding polygalacturonase (PG) and pectin methyltransferase (Smith et al., 1990; Asif and Nath, 2005), heat shock proteins (Gray et al., 1992 and 1994), histidine decarboxylase (Picton et al., 1993a) as well the multigene families encoding the ethylene biosynthesis pathway enzymes ACC oxidase (Hamilton et al., 1990; Flores et al., 2002; Xiong et al., 2005) and ACC synthase (Theologis, 1992; Hidalgo et al., 2005).

Other experimental methodologies allowed the isolation of genes whose expression is regulated by ethylene and/or ripening. Many natural tomato mutants affected at ripening have been used to study gene expression and regulation. Two principal groups of mutants were used, i.e. those whose mutation affects only the color of the ripe fruit and those whose mutation determines the pleiotropic effects occurring during ripening. The pleiotropic mutant rin

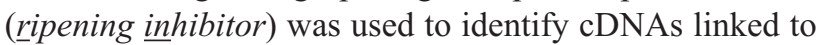
ripening and resulted in the isolation of the ERT series of clones including ERT1, ERT10 and ERT15, which correspond to mRNAs that specifically accumulate during ripening (Picton et al., 1993b). Treatment of the rin mutant with ethylene allowed transcription of genes corresponding to some of these mRNAs, indicating that the rin-type fruits possess the capacity to respond to ethylene (Lincoln and Fischer, 1988; Knapp et al., 1989) but in spite of the fact that gene expression is restored, such treatment is unable to induce normal ripening. This suggests either the absence of a specific receptor to ripening in the transduction pathway or a deficiency in the ethylene signal transduction cascade, linking perception of this phytohormone to the ripening responses. Dellapenna et al. (1989) used the nor (nonripening) and $N r$ (Never ripe) mutants to study the regulation of other cDNAs expressed during ripening, such mutants having been studied because they can provide interesting clues for the elucidation of many aspects of the fruit ripening process, ethylene perception and signaling (Vrebalov et al., 2002; Barry et al., 2005).

\section{Genetic manipulation of fruit ripening}

To identify the function of genes and their role in the ripening process, an antisense RNA strategy has been used by several research groups and several transgenic plants showing reduced expression of ripening related genes have been obtained (Gray et al., 1994; Stearns and Glick, 2003). Transgenic tomato plants expressing an antisense polygalacturonase gene showed a reduction in $\mathrm{PG}$ transcripts as well in enzymatic activity during ripening and it was has been shown that in fruits with antisense PG the degradation of cellular wall pectins was inhibited but other aspects of maturation, such as ethylene production and lycopene accumulation were not affected (Smith et al., 1990; Brummell and Harpster, 2001).

Other transgenic plants, genetically modified to get alter ethylene production have been obtained by various authors. Fruits from plants transformed with an antisense ACC oxidase clone showed a strong reduction in ethylene production, delayed ripening and a considerable increase in conservation period (Hamilton et al., 1990; Xiong et al., 2005). Melon, genetically transformed using a melon antisense ACCO clone resulted in a considerable reduction in fruit ethylene synthesis and, unlike wild type fruits, they showed no increase in ethylene production during peak respiration (climacteric crisis) either when attached to the plants or post-harvest (Ayub et al., 1996). These melons showed an inhibition of maturation as indicated by the absence of yellowish of peel and much reduced softening coupled with a high sugar concentration produced as a result of the prolonged ripening time (Ayub et al., 1996). In all cases, ripening of transgenic fruits can be restored by the application of exogenous ethylene (Zegzouti, 1997).

To block ethylene biosynthesis an antisense ACCS clone which completely blocked ripening was introduced into tomato (Oeller et al., 1991; Knoester et al., 1997). Other tomato models involved a modification of the ethylene biosynthetic pathway by the over-expression of a bacterial ACC deaminase (Klee et al., 1991, Glick, 2004) or the expression of a bacteriophage gene encoding a S-adenosylmethionine hydrolase (Good et al., 1994), which causes a reduction in ethylene production and delayed ripening. The genetic manipulation of alcohol dehydrogenase levels in ripening tomato fruit have been shown to affect the balance of some flavor aldehydes and alcohols (Speirs et al., 2001).

\section{Ethylene Perception and Signal Transduction Pathway}

Much information concerning the biochemical components of the ethylene perception and signal transduction pathways of ethylene have been obtained during the past decade through the development of molecular and genetic strategies using $A$. thaliana as plant model. These studies have provided strong evidence that ethylene signaling is 
mediated by a family of $\mathrm{Cu}^{+2}$-containing receptors signaling through a pathway that includes a MAP kinase cascade, a metallic transporter intermediate and a transcriptional cascade (Bleecker and Kende, 2000; Giovannoni, 2004; Stepanova and Alonso, 2005). The components of ethylene signal transduction cascade are described below.

\section{Ethylene receptors}

The process of ethylene perception starts when this molecule interacts with a receptor linked to the endoplasmic reticulum (ER) membrane (Giovannoni, 2004; Stepanova and Alonso, 2005). The pleiotropic effects of the etr 1 mutation in A. thaliana suggested that this gene could either encode an ethylene receptor or act at an early stage in the signal transduction cascade in wild-type plants. As a matter of fact, the ETR1 gene from A. thaliana was cloned using chromosome walking techniques (Chang et al., 1993). This gene encodes a protein whose N-terminal hydrophobic end forms a dimmer linked by an S-S bond (Shaller and Bleecker, 1995) responsible for its location in the membrane. The C-terminal end shows high homology with the histidine-kinase family proteins implicated in signal transduction in prokaryotes known as the two-component system (Johnson and Ecker, 1998).

The expression of the coding region of this gene in yeasts showed that the ETR1 protein binds to the plasma membrane as a dimmer and is also capable of binding ethylene and that the ETR1 protein acts as an ethylene receptor (Shaller and Bleecker, 1995), while Rodriguez et al. (1999) demonstrated that ETR1 is a metaloprotein possesses a $\mathrm{Cu}^{+2}$ ion at the ethylene binding site.

Besides ETR1, four related genes (ERS, ETR2, EIN4 and $E R S 2$ ) have been isolated in Arabidopsis (Bleecker and Kende, 2000; Giovannoni, 2004; Stepanova and Alonso, 2005). The five members of the ETR family are related on the basis of the common structural elements in the protein. Additionally, specific substitutions of amino acids in the ethylene binding domain in all members confer dominant insensibility to this hormone in whole plants. Homologues genes to the ETR1 family have been identified and cloned in tomato, including the NR eTAE1 and LeETR1, LeETR2, LeETR4 and LeETR5 genes (Wilkinson et al., 1995; Tieman and Klee, 1999; Hall and Bleecker, 2003).

There are strong indications that ethylene receptors act as negative regulators of the ethylene signal transduction pathway and that they are activated in the absence of ethylene acting direct or indirectly in the activation of a cascade downstream component, denominated the CTR1 (constitutive-triple-response) (Giovannoni, 2004; Stepanova and Alonso, 2005).

\section{CTR1}

The study of mutants showing a constitutive response to ethylene in its absence culminated with the isolation and cloning of the constitutive-triple-response 1 (CTRl) gene coding for a kinase with high homology to the Raf family of serine/threonine kinases (MAPKKK) (Kieber et al., 1993). Later, several CTR1 homologous were isolated from tomato (Jones, 1999; Zegzouti et al., 1999; Leclercq et al., 2002; Adams-Phillips et al., 2004 a). The CTR1 product acts downstream of ETR1, ETR2, ERS1, ERS2 and EIN4 in the ethylene signal transduction pathway and corresponds to a negative regulator of other cascade components identified in Arabidopsis, including the ethylene-insensitive genes (EIN2 and EIN3) and the ethylene-response-factor (ERF1) (Giovannoni, 2004; Stepanova and Alonso, 2005).

\section{Transcription factors}

Studies shown that transcription factors are part of the ethylene signal transduction pathway, with the cloning of the EIN3 gene encoding a nuclear protein providing the first direct evidence of nuclear regulation in this transduction pathway (Chao et al., 1997). The EIN3-like proteins (EILs, e.g. EIL1 and EIL2) also belong to this family and are regulated by upstream cascade components (Bleecker and Kende, 2000; Giovannoni, 2004; Stepanova and Alonso, 2005).

The search for promoters for the EIN3 gene family led to the identification of the ERF1 gene (Solano et al., 1998), a member of the large family of plant-specific transcription factors called ethylene-response-elementbinding-proteins (EREBPs) originally identified as DNAbinding proteins which bind to promoter-specific elements in ethylene-inducible elements (Ohme-Takagi and Shinshi, 1995). In Arabidopsis the expression of the ERF1 gene is rapidly induced by treatment with ethylene (Solano, et al., 1998). Another relevant fact is that EIN 3 homodimmers are capable of having in vitro interactions with a promoter element in the ERF1 gene. When ERF1 is constitutively expressed in EIN3 mutants it activates a group of responses to ethylene. This indicates that ERF1 is part of the primary signal transduction cascade and is downstream of the previously identified components, suggesting that a transcriptional cascade operates in ethylene signaling (Bleecker and Kende, 2000, Giovannoni, 2004; Stepanova and Alonso, 2005). Recently, four new members of the ERF family of plant-specific DNA-binding (GCC box) factors have been isolated from tomato fruit (LeERF1-4) and are being characterized (Tournier et al., 2003).

Emerging genomics tools including expressed sequence tags (ESTs) and expression arrays are also likely to accelerate the discovery of homologous genes from additional species and the identification of additional novel ripening regulators (Adams-Phillips et al., 2004 b).

\section{Model for ethylene perception and signal transduction pathway}

Several theories on ethylene signal perception and transduction have been proposed to explain the mechanisms by which ethylene receptors could promote signal 
transduction through a cascade involving several components (Zarembinski and Theologis, 1994; Ecker, 1995; Bleecker and Kende, 2000).

The model recently proposed by Bleecker and Kende (2000) and subsequently reviewed by Giovannoni (2004) and Stepanova and Alonso (2005) places the components of the ethylene signal transduction pathway in a linear array and defends the theory that ethylene negatively regulates the joint binding of ETR 1 and CTR 1 to the receptor, resulting in de-repression of response pathways (Figure 2). The order of the components in this hypothetical linear chain is based on the analysis of epistatic genes, gene expression studies and the study of biochemical interactions. In this model, ethylene negatively regulates the family of receptors associated with the endoplasmic reticulum membrane and which are related to the two-component catalytic bacterial receptor family. The histidinekinase transmitter domains of members of this receptor family interact with the CTR1 Raf-like kinase regulator domain. This CTR1 receptor/complex negatively regulates a membrane protein (EIN2) which is related to a super-family of metal-transporters. The C-terminal cytoplasmic EIN2 domain signals positively downstream of the EIN3 transcription factor family located in the nucleus. A target for the EIN3 transcription factors is the ERF1 gene promoter, which is a member of a second family of transcription factors and is rapidly induced in response to ethylene and is capable of activating a set of responses to ethylene when expressed.

\section{Recent Developments on Plant Hormone Ethylene Role on Climacteric Fruits Ripening}

The large diversity of gene types is representative of the multitude of events affected by ethylene during fruit ripening. Ethylene receptor genes and components of the ethylene transduction pathway have been discovered in the recent years, as described above. However, the number of genes demonstrated to be induced through this pathway is low in regard to the variety of physiological responses of plants to ethylene.

For this reason, novel early ethylene-regulated (ER) genes from late immature green tomato fruit have been isolated using the differential display technique, in order to obtain a broader understanding of the molecular basis by which ethylene coordinates the ripening process (Zegzouti et al., 1999). A large set of clones have been isolated, showing homologous genes involved in transcriptional and post-transcriptional regulation, signal transduction components, stress-related proteins and primary metabolism. However, as yet a number of these $E R$ clones have no assigned function and reverse genetics is currently being used to investigate the function of these genes and address their role in the ripening process (Pech et al., 2002). The latest data have indicated that ER50 is a CTR-like clone, potentially involved in the ethylene transduction pathway (Leclercq et al., 2002; Adams-Phillips et al., 2004a) and ER24 is homologous to a multi-bridging factor involved in transcriptional activation (Tournier et al., 2003) while ER49 is a putative mitochondrial translation elongation factor that could be involved in the stimulation of mitochondrial activity by ethylene during the climacteric increase in respiration (Chaves et al., 2002; Benichou and Li et al., 2003). These genes are being extensively studied in order to determine their function and mechanisms of regulation by ethylene. The functional characterization involves several studies, including molecular, biochemical and physiologic analysis and the determination of expression profiles.

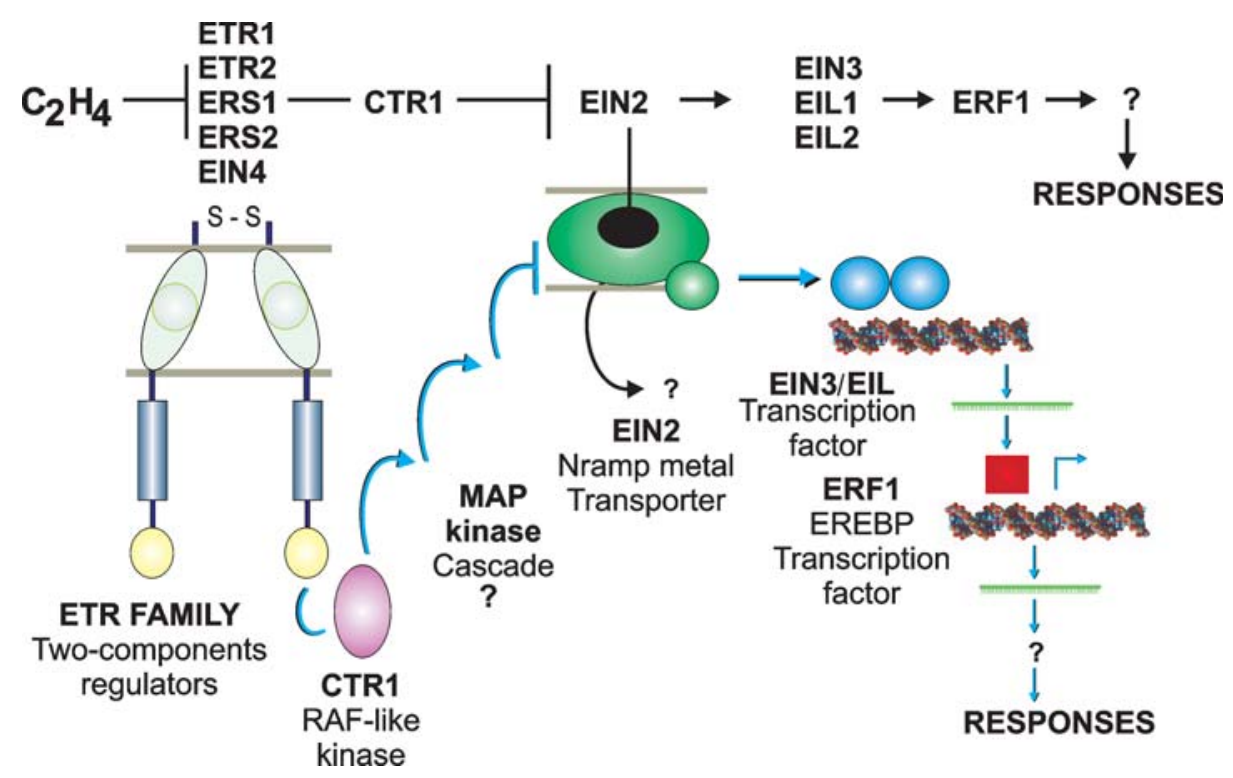

Figure 2 - Genetic interactions and biochemical identities of the ethylene signal transduction pathway components (from Bleecker and Kende, 2000). 


\section{Final Considerations}

Ethylene, in association with other hormones and developmental factors plays a major role in climacteric fruit ripening, a complex developmental process. At present there is a large amount of information on ethylene and fruit ripening, much of which was gathered at a time when gas was used for illumination. Time has moved on and we are now living in the 'genomic era' in which the role of the phytohormone ethylene on the development and fruit ripening processes may be very important in developing new strategies on fruit and vegetable conservation and in obtaining biotechnological products of high aggregated value by genetically engineering commercial plant varieties.

\section{Acknowledgments}

The authors would like to thank Dr. Jean-Claude Pech, Dr. Alain Latché, Dr. Mondher Bouzayen and Dr. Hicham Zegzouti for their contribution to this article and for their precious advise during all the years of workgroup.

\section{References}

Abeles FB, Morgan PW and Saltveit ME (1992) Ethylene in plant biology. San Diego Academic Press, San Diego, 414 pp.

Adams-Phillips L, Barry C, Kannan P, Leclercq J, Bouzayen M and Giovannoni J (2004a) Evidence that CTR1-mediated ethylene signal transduction in tomato is encoded by a multigene family whose members display distinct regulatory features. Plant Mol Biol 54:387-404.

Adams-Phillips L, Barry C and Giovannoni J (2004b) Signal transduction systems regulating fruit ripening. Trends Plant Sci 9:331-338.

Asif MH and Nath P (2005) Expression of multiple forms of polygalacturonase gene during ripening in banana fruit. Plant Physiol Biochem 43:177-184.

Ayub R, Guis M, Ben Amor M, Gillot L, Roustan JP, Latché A, Bouzayen M and Pech JC (1996) Expression of ACC oxidase antisense gene inhibits ripening of cantaloupe melon fruits. Nat Biotechnol 14:862-866.

Barry CS, McQuinn RP, Thompson AJ, Seymour GB, Grierson D and Giovannoni JJ (2005) Ethylene insensitivity conferred by the Green-ripe and Never-ripe 2 ripening mutants of tomato. Plant Physiol 138:267-275.

Benichou M, Li Z, Tournier B, Chaves ALS, Zegzouti H, Jauneau A, Delalande C, Latché A, Bouzayen M, Spremulli LL and Pech JC (2003) Tomato EF-Ts(mt), a functional traslation elongation factor from higher plants. Plant Mol Biol 53:411-422.

Bleecker AB and Kende H (2000) Ethylene: A gaseous signal molecule in plants. Annu Rev Cell Biol 16:1-18.

Brady CJ (1987) Fruit ripening. Annual Review of Plant Physiol 38:155-178.

Brummell DA and Harpster MH (2001) Cell wall metabolism in fruit softening and quality and its manipulation in transgenic plants. Plant Mol Biol 47:311-340.

Chang C, Kwok SF, Bleecker AB and Meyerowitz EM (1993) Arabidopsis ethylene-response gene ETR1: Similarity of product to two-component regulators. Science 262:539-544.
Chao Q, Rothenberg M, Solano R, Roman G, Terzaghi W and Ecker JR (1997) Activation of ethylene gas response pathway in Arabidopsis by the nuclear protein ethyleneinsensitive 3 and related proteins. Cell 89:1133-1144.

Chaves ALS, Silva JA, Pech JC, Latche A, Bouzayen M, Zegzouti $\mathrm{H}$ and Rombaldi CV (2002) Characterisation of ER49, a Ts type protein synthesis elongation factor, expressed during tomato fruit maturation. Braz J Plant Physiol 14:21-30.

Dellapenna D, Lincoln JE, Fischer RL and Bennet AB (1989) Transcriptional analysis of polygalacturonase and other ripening associated genes in Rutgers, rin, nor and $\mathrm{Nr}$ tomato fruit. Plant Physiol 90:1372-1377.

Ecker JR (1995) The ethylene signal transduction pathway in plants. Science 268:667-675.

Flores F, El Yahyaoui F, de Billerbeck G, Romojaro F, Latché A, Bouzayen M, Pech JC and Ambid C (2002) Role of ethylene in the biosynthetic pathway of aliphatic ester aroma volatiles in Charentais Cantaloupe melons. J Exp Bot 53:201-206.

Giovannoni JJ (2004) Genetic regulation of fruit development and ripening. Plant Cell 16 Suppl:S170-180.

Glick BR (2004) Bacterial ACC deaminase and the alleviation of plant stress. Adv Appl Microbiol 56:291-312.

Good X, Kellogg JA, Wagoner W, Langhoff D, Matsumura W and Bestwick RK (1994) Reduced ethylene synthesis by transgenid tomatoes expressing S-adenisylmethionine hydrolase. Plant Mol Biol 26:781-790.

Gray J, Picton S, Giovannoni JJ and Grierson D (1994) The use of transgenic and naturally occurring mutants to understand and manipulate tomato fruit ripening. Plant Cell Environ 17:557-571.

Gray J, Picton S, Shabbeer J, Schuch W and Grierson D (1992) Molecular biology of fruit ripening and its manipulation with antisense genes. Plant Mol Biol 19:69-87.

Hall AE and Bleecker AB (2003) Analysis of combinatorial loss-of-function mutants in the Arabidopsis ethylene receptors reveals that the ers 1 etr1 double mutant has severe developmental defects that are EIN2 dependent. Plant Cell 15:2032-2041.

Hamilton AJ, Lycett GW and Grierson D (1990) Antisense gene that inhibits synthesis of the hormone ethylene in transgenic plants. Nature 346:284-287.

Hidalgo MS, Tecson-Mendoza EM, Laurena AC and Botella JR (2005) Hybrid 'Sinta' papaya exhibits unique ACC synthase 1 cDNA isoforms. J Biochem Mol Biol 38:320-327.

Iki K, Sekigushi K, Kurata K, Tada T, Nakagawa H, Ogura N and Takehana H (1978) Immunological properties of $\beta$-fructofuranosidase from ripening tomato fruit. Phytochemistry 17:311-312.

Jeffery D, Smith C, Goodenough P, Prosser I and Grierson D (1984) Ethylene-independent and ethylene-dependent biochemical changes in ripening tomatoes. Plant Physiol 74:32-38.

Johnson B and Ecker JR (1998) The ethylene gas signal: Transduction pathway. Annu Rev Genet 32:227-254.

Jones B (1999) La régulation transcriptionelle au cours des stades préclimactériques chez la tomate: Isolement et caractérisation fonctionnelle des facteurs de transcription de l'auxine. $\mathrm{PhD}$ thesis, Ecole Nationale Supérieure Agronomique de Toulouse, Toulouse.

Kende H (1993) Ethylene biosynthesis. Annu Rev Plant Physiol Plant Mol Biol 44:283-307. 
Kieber JJ, Rothenberg M, Roman G, Feldman KA and Ecker JR (1993) CTR1, a negative regulator of the ethylene response pathway in Arabidopsis, encodes a member of a Raf family of protein kinases. Cell 72:427-441.

Klee HJ, Hayford MB, Kretzmer KA, Barry GF and Kishore GM (1991) Control of ethylene synthesis by expression of a bacterial enzyme in transgenic tomato. Plant Cell 3:1187-1193.

Knapp J, Moureau P, Schuch W and Grierson D (1989) Organization and expression of polygalacturonase and other ripening related genes in Ailsa Craig "Neverripe" and "Ripening inhibitor" tomato mutants. Plant Mol Biol 12:105-116.

Knoester M, Linthorst HJM, Bol JF and van Loon LC (1997) modulation of stress-inducible ethylene biosynthesis by sense and antisense gene expression in tobacco. Plant Sci 126:173-183.

Leclercq J, Adams-Phillips LC, Zegzouti H, Jones B, Latché A, Giovannoni JJ, Pech JC and Bouzayen M (2002) LeCTR1, a tomato CTR1-like gene, demonstrates ethylene signaling ability in Arabidopsis and novel expression patterns in tomato. Plant Physiol 130:1132-1142.

Lincoln JE and Fischer RL (1988) Regulation of gene expression by ethylene in wild-type and rin tomato (Lycopersicon esculentum) fruit. Plant Physiol 88:370-374.

Mansson PE, Hsu D and Stalker D (1985) Characterization of fruit specific cDNAs from tomato. Mol Gen Genet 200:356-361.

Oeller PW, Wong LM, Taylor LP, Pike DA and Theologis A (1991) Reversible inhibition of tomato fruit senescence by antisense RNA. Science 254:437-439.

Ohme-Takagi M and Shinshi H (1995) Ethylene-inducible DNA binding proteins that interact with an ethylene-responsive element. Plant Cell 7:173-182.

Pech JC, Latché A and Balagué C (1992) Cellular and molecular aspects of the plant hormone ethylene. Kluwer Academic Publishers, Netherlands, $385 \mathrm{pp}$.

Pech jc, sharkawi I, chaves ALS, li Z, lelièvre jm, bouzayen m, frasse P, zegzouti $\mathrm{H}$ and latché A (2002) Recent developments on the role of ethylene in the ripening of climacteric fruits. Acta Hortic 587:489-495.

Picton S, Gray J, Payton S, Barton SL, Lowe A and Grierson D (1993a) A histidine decarboxylase-like mRNA is involved in tomato fruit ripening. Plant Mol Biol 23:627-631.

Picton S, Gray J, Barton S, Abubakar U, Lowe A and Grierson D (1993b) cDNA cloning and characterisation of novel ripening-related mRNAs with altered patterns of accumulation in the ripening inhibitor ( $r i n)$ tomato ripening mutant. Plant Mol Biol 23:193-207.

Rodriguez FI, Esch JJ, Hall AE, Binder BM, Shaller GE and Bleecker AB (1999) A copper cofactor for the ethylene receptor ETR1 from Arabidopsis. Science 283:996-998.

Seymour GB, Taylor JE and Tucker GA (1993) Biochemistry of fruit ripening. Chapman and Hall Publishers, London, $454 \mathrm{pp}$.

Shaller GE and Bleecker AB (1995) Ethylene binding sites generated in yeast expressing the Arabidopsis ETR1 gene. Science 270:1809-1811.

Smith CJ, Watson CF, Bird CR, Ray J, Schuch W and Grierson D (1990) Expression of a truncated tomato polygalacturonase gene inhibits expression of the endogenous gene in transgenic plants. Mol Gen Genet 224:477-481.

Solano R, Stepanova A, Chao Q and Ecker JR (1998) Nuclear events in ethylene signaling: A transcriptional cascade mediated by ethylene-insensitive 3 and ethylene-response-factor1. Genes Dev 12:3703-3714.

Speirs J, Lee E, Holt K, Yong-Duk K, Steele Scott N, Loveys B and Schuch W (2001) Genetic manipulation of alcohol dehydrogenase levels in ripening tomato fruit affects the balance of some flavor aldehydes and alcohols Plant Mol Biol 47:311-340.

Stearns JC and Glick BR (2003) Transgenic plants with altered ethylene biosynthesis or perception. Biotechnol Adv 21:193-210.

Stepanova A and Alonso J (2005) Ethylene signaling and response pathway: A unique signaling cascade with a multitude of inputs and outputs. Physiol Plant 123:195-206.

Theologis A (1992) One rotten apple spoils the whole bushel: The role of ethylene in fruit ripening. Cell 70:181-184.

Tieman DM and Klee HJ (1999) Differential expression of two novel members of the tomato ethylene receptor family. Plant Physiol 120:165-172.

Tournier B, Sanchez-Ballesta MT, Jones B, Pesquet E, Regad F, Latché A, Pech JC and Bouzayen M (2003) New members of the tomato ERF family show specific expression pattern and diverse DNA-binding capacity to the GCC box element. FEBS Lett 550:149-154.

Tucker GA and Grierson D (1982) Synthesis of polygalacturonase during tomato fruit ripening. Planta 155:64-67.

Vrebalov J, Ruezinsky D, Padmanabhan V, White R, Medrano D, Drake R, Schuch W and Giovannoni J (2002) A MADS-box gene necessary for fruit ripening at the tomato ripeninginhibitor (rin) locus. Science 296:343-346.

Wilkinson JQ, Lanahan MB, Hsiao-Ching Y, Giovannoni JJ and Klee HJ (1995) An ethylene-inducible component of signal transduction encoded by never-ripe. Science 270:18071809.

Xiong AS, Yao QH, Peng RH, Li X, Han PL and Fan HQ (2005) Different effects on ACC oxidase gene silencing triggered by RNA interference in transgenic tomato. Plant Cell Rep 23:639-646.

Yang SF and Hoffman NE (1984) Ethylene biosynthesis and its regulation in higher plants. Annu Rev Plant Physiol 35:155189.

Zarembinski TI and Theologis A (1994) Ethylene biosynthesis and action: A case of conservation. Plant Mol Biol 26:15791597.

Zegzouti H (1997) Isolement de noveaux gènes regulés par l'éthylène chez la tomate (L. esculentum) par criblage de cDNA issus du "Differential Display". PhD. Thesis, Institut National Polytechnique, Toulouse.

Zegzouti H, Jones B, Frasse P, Marty C, Maitre B, Latché A, Pech JC and Bouzayen M (1999) Ethylene-regulated gene expression in tomato fruit: Characterization of novel ethyleneresponsive and ripening-related genes isolated by differential display. Plant J 18:589-600.

Associate Editor: Márcio de Castro Silva Filho 